\title{
Tajdidukasi
}

Vol. 9, No. 1, January 2019, pp. 29-34

29

\section{Muhammad Syahrûr; Theory of limit (teori batas)}

\author{
Eka Yuhendri \\ Universitas Islam Negeri Sunan Kalijaga Yogyakarta. Jalan Marsda Adisucipto, Yogyakarta, 55281, Indonesia \\ ekahendri85@gmail.com \\ * corresponding author
}

\section{ARTICLE INFO}

Keywords

Muhammad Syahrûr

Theory of limit

Teori batas

\begin{abstract}
Penulis meyakini bahwa, tidak semua klaim pembaharuan terhadap konsep sunnah berbuah baik terhadap ajaran dan amalan-amalan Islam. Bukti konkrit dari pernyataan tersebut adalah klaim pembaharuan konsep sunnah yang ditawarkan oleh Syahrûr. Pembaharuan yang diagungagungkan pada kenyataannya hanya mengulang kembali apa yang telah diungkapkan oleh para orientalis dan pengingkar sunnah. Tentu apa yang disebut pembaharuan tersebut telah dijawab oleh ulama Islam. Seperti klaim sunnah bukanlah wahyu dan sumber hukum Islam. Begitu juga dengan metodologi Syahrur yang bahkan bersandar pada teori-teori yang sangat bertentangan dengan ajaran Islam sendiri dan berimplikasi pada pemutusan rantai epitemologi Islam serta melahirkan kerancuan dalam penerapannya.
\end{abstract}

This is an open access article under the CC-BY-SA license.

\section{PENDAHULUAN}

Sejarah muslim mencatat bahwa pada abad pertengahan telah terjadi kefakuman dalam berijtihad dan berpaling pada sikap taqlid. Era kefakuman ini terjadi setelah masa keemasan dan kemapanan, terutama adanya anggapan sebuah kesempurnaan telah dicapai oleh para imam mazhab dan doktrin pintu ijtihad tertutuppun dikumandangkan. Hak berijtihad secara individu telah digantikan dengan kewajiban untuk taqlid dan ironisnya para ulama menjadi pengekor (muqallid) yang harus menerima dan mengikuti ajaran para pendahulunya yang di anggap sempurna. Singkat cerita, puncaknya terjadi pada pembelaan secara fanatik terhadap pendapat para imam mazhab itu sendiri (Abdullah, 2004).

Kefakuman berlansung cukup lama sejak abad ke-4 Hijriyah sampai dengan abad ke-13 Hijriah, barulah umat Islam tersadar dari tidur panjang, ketika umat muslim melihat peradaban barat maju pesat dengan tekhnologi informasi dan pembaharuan dipelbagai aspek kehidupan. Maka muncullah gagasan pembaharuan yang diserukan oleh sejumlah harakah islamiyyah (pergerakan umat Islam). Semua bersepakat dengan pembaharuan tersebut, hanya saja terdapat perbedaan dalam memandang bagaimana pembaharuan tersebut dilakukan dan diimplementasikan hingga memunculkan metodologis-metodologis yang beragam.

Termasuk sumber hukum Islam (Al-Qur'an dan As-Sunnah) tak luput dari perhatian gerakan ini. Tanpa menghakimi, mengkritik atau menyetujui salah satunya pembaharuan yang menawarkan pembacaan kontemporer terhadap sumber hukum Islam salah satunya, yaitu Muhammad Syahrûr dengan Nazariyyat Al Hudud (theory of limit: selanjutnya di sebut Teori Batas) yang mengundang banyak respon pro dan kontra dari kalangan umat Islam sendiri. Syahrûr memang pandai dan istimewa, meski berlatar belakang mekanik dia mampu melakukan pembacaan kontemporer dengan 
metode hermeneutic terhadap teks sebagai sumber hukum Islam dan memunculkan metode baru yang responsive terhadap pesoalan umat.

Berdasarkan pendahuluan tersebut, dalam malakalah ini penulis sedikit membahas tentang Muhammad Syahrur Siapa Muhammad Syahrûr dan bagaimana Metodologi Tajdidnya, Apa dan bagaimana mengimplementasikan teori batas dan bagaimana pendapat ulama tentang teori batasnya. Memang teori batasnya yang menuai kotroversial dikalangan muslim namun ada harapan, agar dapat dijadikan pemahaman dan memahami Muhammad Syahrûr dan metodologi istinbat hukumnya, mengetahui tentang teori batas serta, mengetahui respon muslim terhadap teori batas.

\section{PEMBAHASAN}

\section{Biografi Muhammad Syahrûr}

Muhammad Syahrûr dilahirkan di Damaskus, Syiria, Mesir pada 11 April 1938 M. ayahnya bernama Daib bin Daib dan ibunya bernama Shadiqah binti Shalih Falyun. Seperti yang penulis sebutkan sebelumnya Muhammad Syahrûr mengawali karirnya di pendidikan dasar dan menengah di kota kelahirannya di lembaga Pendidikan `Abdal-Rahman al-Kawâkibî, hingga tamat pada 1957. Pada 1957 itu juga ia memperoleh beasiswa pemerintah untuk studi ilmu teknik di Moskow (Uni Soviet), Saat di Moskow inilah Muhammad Syahrûr bersentuhan dengan pemikiran Hegel dan Marxisme. Sehingga apa yang telah Ia pelajari ini sedikit banyak mempengaruhi penafsirannya terhadap ayatayat Al-Qur'an sebagaimana tertuang dalam karyanya.

Tahun berikutnya, ia bekerja sebagai dosen pada Fakultas Teknik Universitas Damaskus. Kemudian oleh pihak universitas, ia dikirim ke Irlandia untuk studi Post Graduated (S2/Pascasarjana) dalam spesialisasi mekanik tanah (al-handasah al-turbah) dan teknik fondasi (al-handasat al-asasat) pada Ireland National University. Gelar Master of Science diperoleh ada 1969, dan gelar Doktor pada 1972.

Pada tahun ini pula Syahrûr secara resmi diangkat menjadi dosen Fakultas Teknik Sipil (Kulliyyat al-Handasah al-Madâniyyah) Universitas Damaskus untuk mata kuliah Mekanika Pertanahan dan Geologi (Mikânika al-Turbah wa al-Mansya`at al-Ardhiyyah) hingga sekarang. Selain sibuk sebagai seorang dosen, pada tahun 1972 ia bersama beberapa rekannya di fakultas juga membuka Biro Konsultasi Teknik (Dâr al-Istisyârat al-Handasiyyah). Sepertinya, prestasi dan kreatifitas Syahrûr semakin meneguhkan kepercayaan niversitas terhadapnya, terbukti ia mendapat kesempatan terbang ke Arab Saudi untuk menjadi tenaga ahli pada al-Saud Consult pada tahun 1982-1983.

Meskipun Syahrûr berlatar belakang teknik, ia termasuk pemerhati pada diskursus keislaman saat itu. Perhatian itu tertuang dalam buah karyanya yang berjudul al-Kitâb wa al-Qur ân Qirầah Mu'âshirah. Buku ini merupakan karya perdananya sekaligus menjadi inspirasi untuk menuliskan pemikirannya dalam karya yang lain. Selain itu buku inilah secara fungsional yang sebenarnya telah membuat namanya melejit dalam kancah belantika pemikiran Islam. Secara garis besar, karya-karya Syahrûr dibagi ke dalam dua kategori: Pertama, bidang teknik: al-Handasah al-Asasat (tiga jilid) dan al-Handasah al-Turâbiyyah (sebanyak satu jilid). Kedua, bidang keislaman Dirâsat Islâmiyyah yang kesemuanya diterbitkan oleh al-Ahâlî li al-Thabâ' ah wa al-Nasyr wa al-Tauzi` di Damaskus (Syahrur, 1990, 2000).

\section{Metodologi Tajdid}

Memang menarik jika dikatakan Muhammad Syahrûr seorang tokoh pembaharu mengingat Syahrûr memiliki gagasan pemikiran yang baru dan menantang pemikiran yang di anggapnya telah mapan seperti pemikiran tradisionalisme Islam. Sehingga Syahrûr begitu bersemangat dan berani untuk menyuarakan gagasan pembaharuannya. Pertanyaannya gagasan pembaharuan seperti apa yang dengan lantang diserukannya?

Berangkat dari kegelisahannya, bahwa; (1) adanya produk hukum masa lampau yang diterapkan pada masa kini, tentunya hal ini memerlukan metologi fikih baru menggantikan fikih yang lama, (2) produk fikih yang sekarang tidak lagi relevan dengan tuntutan modernitas sehingga diperlukan formulasi fikih baru, (3) tidak adanya epistemologi Islam yang valid sehingga berdampak pada 
fanatisme dan doktrin mazhab sehingga pemikiran Islam menjadi sempit, terhambat jika tidak mau dikatan tidak berkembang (Badarussyamsi, 2016). Dan masih banyak kegelisahan lain yang membuat Syahrûr berfikir keras untuk proyek pembaharuan yang di serukannya.

Dari pokok pikiran dan kegelisahan Syahrûr di atas, Nampak sekali Syahrûr berupaya mengkritik pemikiran Islam yang di dominasi oleh pemikiran yang lemah, mengandung kekeliruan. Mengkritik kelompok salafi dan keluar dari pemikiran tradisional. Dan dengan berani menawarkan pokok-pokok pemikiran dalam upaya merekonstruksi pemikiran Islam. Syahrûr juga mengungkapkan, bahwa: (1) tidak ada jalan lain untuk memahami teks kecuali dengan analisis rasional, (2) kebenaran teks tidak terletak pada keindahan dan kecantikan retorikanya, melainkan pada substansi dan keadaan sebenarnya dari teks, (3) ketika Al Qur'an telah di wahyukan dan ditafsirkan pada masa lampau, mestinya juga berubah agar dapat bermanfaat bagi kehidupan masyarakat saat ini terakhir, (4) $\mathrm{Al}$ Qur'an menjamin kesesuaian dan kesempurnaan Antara naskah kitab dengan realitas keberadaan manusia.

Prinsip-prinsip inilah yang memunculkan ide besar dan kontoversial, antara lain adalah tentang konsep "sunnah". Muhammad Syahrûr tidak mempunyai keyakinan bahwa "sunnah" bukanlah bagian dari wahyu dan sumber hukum Islam. Syahrur dengan tegas menentang mayoritas ulama yang menyatakan bahwa sunnah adalah wahyu berdasarkan firman Allah dalam QS. al-Najm: 3-4; "Dan tiadalah yang diucapkannya itu menurut kemauan hawa nafsunya. Ucapannya itu tiada lain hanyalah wahyu yang diwahyukan (kepadanya)."

Syahrûr melihat bahwa dhamir huwa pada ayat tersebut maksudnya adalah ayat-ayat al-Qur'an yang diucapkan (yantiq) oleh Nabi Muhammad. Sehinggga substansi ucapan Nabi tidak merujuk kepada umumnya perkataan Nabi, melainkan al-Qur'an yang diwahyukan kepada lisannya. Karena secara konteks ayat ini diturunkan di Mekkah ketika orang Arab tidak meragukan pribadi Nabi tetapi apa yang diwahyukan kepadanya. Syahrur menambahkan bahwa jika memang yang dimaksudkan dalam ayat ini adalah sunnah, maka pendapat itu ditentang sendiri oleh kenyataan perbuatan Nabi pernah ditegur oleh ayat al-Qur'an (Syahrur, 1990). Tentu sangatlah ganjil jika ada wahyu (sunnah Nabi) ditegur oleh wahyu sendiri (al-Qur'an).

Sumber hukum Islam lainnya seperti ijma' pun didekonstruksi, bukan sebagai kesepakatan para sahabat dan 'Ulama. Bahkan meragukan akan keadilan dan konsensus (ijma') sahabat. Ia mengatakan, "Kitabullah sudah cukup, tidak perlu hal lain untuk memahaminya, kuncinya ada di dalam, bukan di luar. Maka kita tidak perlu Abu Hurairah, tidak perlu Ibn 'Abbas. " Ia mendefinisikan ijma' sebagai kesepakatan orang-orang yang semasa masih hidup di majlis-majlis perwakilan rakyat dan parlemenparlemen. Orang-orang yang masih hidup dan bersepakat atas masalah penting bagi mereka dalam lingkup perjalanan sejarah yang mereka alami adalah orang-orang yang mampu memahami dan mengatasi problem-problem mereka. Mereka tidak membutuhkan para sahabat, tabi'in, dan para ulama besar terdahulu.

Ia pun menggugurkan konsep qiyas, yang dikatakannya mengacu dan membawa masalah ke masa lampau serta tidak berarti sama sekali. Karena menurutnya, dia berulang kali katakan, bahwa penerapan hukum pada alam realitas adalah aplikasi relatif-historis. Prinsip yang ia gunakan hanya akal pikiran dengan realitas objektif. Pengertian qiyas menurutnya, yakni "mengemukakan dalil-dalil dan bukti-bukti atas kesesuaian ijtihad tentang hal-hal yang dinashkan oleh al-Qur'an dengan kenyataan hidup secara objektif (Armayant, 2010).

\section{Teori Batas (Theory of Limit)}

\section{Pengertian}

Dalam buku al-Kitâb wa al-Qur'ân Qirâ'ah Mu'âshirah yang kemudian di terjemahkan oleh Sahiron Syamsudin dan Burhanudin Zikri; Wael B. Hallaq (University of McGill, Canada) mengungkapkan dalam pengantarnya yang menggambarkan teori batas sebagai berikut:

"Perintah Tuhan yang diungkapkan dalam Al-Qur'an dan Sunnah mengatur ketentuan-ketentuan yang merupakan batas terendah dan batas tertinggi bagi seluruh perbuatan manusia. Batas terendah mewakili ketetapan hukum minimum dalam sebuah kasus hukum, dan batas tertinggi mewakili batas maksimumnya (Syahrur, 2007)." 
Argument lainnya adalah, hukum selalu berbicara tentang batas, yaitu batas minimum dan batas maksimum. Yang kemudian oleh Muhammad Syahrûr dibedakan menjadi 6 (enam) bentuk batasanbatasan. Pembagian inilah yang salah satunya di anggap sebagai rekonstruksi pemikiran hukum Islam.

\section{Aplikasi Teori Batas (Batasan dalam Penetapan Hukum)}

Batas Minimal

Misalnya dalam hal macam-macam makanan yang diharamkan. Maksudnya jenis-jenis makanan dan minuman yang diharamkan dalam al-Qur'an limitasinya bersifat minimal (Q.S. Al-Maidah [5]: 3), Q.S. Al-An'am [6]: 145-156). Selain itu berlaku juga pada perempuan yang dilarang dalam alQur'an untuk dinikahi perempuan yang sedarah. Menikah dengan anggota keluarga yang termasuk kategori hubungan darah dilarang, yang diperbolehkan adalah dengan menikah dengan kerabat lain di luar dari yang disebut dalam Al-Qur'an Surat An-Nisa [4] 22-23. Selanjutnya juga berlaku pada hutang piutang \{QS. Al-Baqarah [2]: 283-284), dan pakaian wanita (QS. An-Nisa' [4]: 31).

\section{Batas Maksimal}

Contohnya hukuman bagi tindak pidana pencurian, hukuman potong tangan yang disebutkan dalam Qur'an merupakan bentuk hukuman maksimal. Jadi, dimungkinkan adanya hukuman dalam bentuk lain yang kualitasnya di bawah hukuman potong tangan. Berlaku pada tindak pidana pencurian (QS. Al-Maidah [5]: 38) dan pembunuhan (QS. Al-Isra' [17]: 33, Al-Baqarah [2]: 178, An-Nia' [4]: 92).

\section{Batas Minimal dan Maksimal Bersamaan}

Yakni yang berlaku dalam hukum waris ( $f a r a ' i d)$. Bagian anak laki-laki yang dua kali lipat anak perempuan merupakan batas atasnya, sementara bagian anak perempuan yang hanya setengah bagian anak laki-laki merupakan batas bawahnya. Maksudnya bagian anak laki-laki sudah mentok, tidak bisa lagi ditambah, tetapi dimungkinkan untuk dikurangi hingga mendekati perimbangan dengan bagian anak perempuan. Sebaliknya, bagian anak perempuan tidak dapat lagi dikurangi, tetapi dimungkinkan untuk ditambah hingga mendekati perimbangan dengan bagian anak laiki-laki. Pemberlakuan batas ini berlaku pada hukum waris (QS. An-Nisa' [4]: 11-14, 176) dan poligami (QS. An-Nisa' [4]: 3).

Batas Minimal dan Maksimal Bersamaan dalam satu titik atau posisi Lurus atau Penetapan hukum Partikular (Ainiyah)

Dengan kata lain ketentuan yang batas bawah dan atasnya berada dalam satu garis sehingga ia tidak dapat dikurangi maupun ditambahi, dan ini berlaku pada hukuman bagi orang yang berbuat zina (100 kali jilid) dengan syarat adanya empat orang saksi atau dengan melalui prosedur li'an. Berlaku pada hukum zina dengan seratus kali cambuk (QS. An-Nur [24]: 2).

\section{Posisi batas maksimum dengan satu titik mendekati garis lurus tanpa persentuhan}

Ketentuan ini berlaku pada pergaulan laki-laki dan perempuan di mana batas bawahnya berupa kondisi tidak adanya persentuhan (interaksi) sama sekali di antara lawan jenis, sementara batas atasnya adalah zina. ketentuan yang memiliki batas atas yang bernilai positif $(+)$ dan batas bawah yang negatif (-). Batas atas tidak boleh dilampaui, sementara batas bawah boleh. Dalam bentuk keenam inilah pandangan Syahrur tentang riba ditempatkan.

\section{Batas maksimum 'positif' tidak boleh dilewati dan batas bawah "negative" boleh dilewati}

Sebagai contoh, dalam hal hubungan kebendaan di antara sesama manusia. Batas atas, yang positif (+) berupa riba, sedangkan batas bawah yang negatif (-) berupa zakat. Batas bawah bisa dilampaui, yakni dengan memberikan sedekah sunat, di samping membayar zakat yang memang hukumnya wajib. Di antara kedua batas ini (positif dan negatif) terdapat keadaan yang bernilai nol, yang wujudnya berupa pemberian kredit dengan tanpa memungut bunga (alqard al-hasan).

Setelah menghimpun dan menganalisis sejumlah ayat yang berkenaan dengan riba, Syahrur menyimpulkan adanya empat poin penting mengenai riba yang mesti diperhatikan, yaitu: (i) riba dikaitkan dengan sedekah, (ii) riba dikaitkan dengan zakat, (iii) ditetapkannya batas atas bagi bunga (riba) yang dipungut, dan (iv) adanya kondisi yang bernilai nol. 
Menurutnya, kendati riba merupakan persoalan yang sangat pelik, bahkan bagi Umar ibn alKhattab sekalipun, namun karena keterkaitannya dengan zakat dan sedekah begitu kokoh-sementara keduanya cukup jelas maknanya-maka untuk menyingkap makna riba dapat dilakukan dengan memahami kedua hal tersebut (zakat dan sedekah). Melalui kerangka analisis semacam ini, setelah sebelumnya ia memaknai riba dengan tumbuh dan tambah, Syahrur akhirnya menyimpulkan adanya tiga kondisi menyangkut riba (Syahrur, 2007).

\section{Pendapat Ulama tentang Teori Batas}

Pendapat yang Mendukung

Pendukung utama dari Muhamad Syahrûr banyak muncul dari kalangan akademisi barat yang mendukung pemikirannya antara lain Wael B. Hallaq, Charlez Kurzman dan bahkan Eickelman sampai menyebut Syahrur sebagai Immanuel Kant bangsa Arab.

Pendapat yang Menentang

Dari kalangan yang kontra pun tidak sedikit, kelompok ini didominasi oleh para ulama dari dunia Arab, seperti Said Ramadhan al-Buti, Yusuf al-Shaidawi, bahkan tokoh yang disandingkan dengannya dalam hal dekonstrusi pembacaan nas agama, Nasr Hamid Abu Zaid juga mengkritiknya.

\section{SIMPULAN}

Penulis meyakini bahwa, tidak semua klaim pembaharuan terhadap konsep sunnah berbuah baik terhadap ajaran dan amalan-amalan Islam. Bukti konkrit dari pernyataan tersebut adalah klaim pembaharuan konsep sunnah yang ditawarkan oleh Syahrûr. Pembaharuan yang diagung-agungkan pada kenyataannya hanya mengulang kembali apa yang telah diungkapkan oleh para orientalis dan pengingkar sunnah. Tentu apa yang disebut pembaharuan tersebut telah dijawab oleh ulama Islam. Seperti klaim sunnah bukanlah wahyu dan sumber hukum Islam. Begitu juga dengan metodologi Syahrur yang bahkan bersandar pada teori-teori yang sangat bertentangan dengan ajaran Islam sendiri dan berimplikasi pada pemutusan rantai epitemologi Islam serta melahirkan kerancuan dalam penerapannya.

Namun dari uraian makalah ini dapat disimpulkan bahwa Muhammad Syahrûr lahir di Damaskus, Syiria, Mesir pada 11 April 1938 M. Pendidikan dasar dan menengah berlansung di Damaskus, memperoleh gelar Diploma dibidang Tekhnik Sipil di Moscow Uni Soviet pada tahun 1964. Gelar Master Science dalam bidang Mekanika Pertanahan dan Fondasi diperolehnya pada 1969, dan Doktor 1972. Dibidang tajdid Muhammad Syahrûr menolak "Sunnah" sebagai sumber hokum kedua setelah Al Qur'an.

Pokok pemikiran Muhammad Syahrûr terbesar ada adalah tentang teori batas yaitu; Pertama, yang hanya memiliki batas minimal. Hal ini berlaku pada perempuan yang boleh dinikahi (QS. [4]: 22-23), jenis makanan yang diharamkan (QS. [5]: 3), [6]: 145-156), hutang piutang \{QS. [2]: 283-284), dan pakaian wanita (QS. [4]: 31). Kedua, yang hanya memiliki batas maksimal. Berlaku pada tindak pidana pencurian (QS. [5]: 38) dan pembunuhan (QS. [17]: 33, [2]: 178, [4]: 92). Ketiga, yang memiliki batas maksimal dan minimal sekaligus. Berlaku pada hukum waris (QS. [4]: 11-14, 176) dan poligami (QS. [4]: 3). Keempat, ketentuan batas minimal dan maksimal berada pada satu titik atau tidak ada alternatif lain dan tidak boleh kurang atau lebih. Berlaku pada hukum zina dengan seratus kali cambuk (QS. [24]: 2). Kelima, ketentuan yang memiliki batas minimal dan maksimal sekaligus, tetapi keduanya tidak boleh disentuh, jika menyentuhnya berarti telah melanggar aturan Tuhan. Berlaku pada hubungan laki-laki dan perempuan. Jika antara laki-laki dan perempuan melakukan perbuatan mendekati zina tetapi belum berzina, maka keduanya belum terjatuh pada batas-batas hudud Allah. Keenam, yang memiliki batas atas dan bawah, di mana batas atasnya bernilai positif dan tidak boleh dilampaui. Sedang batas bawahnya bernilai negatif dan boleh dilampaui. Berlaku pada hubungan kebendaan sesama manusia. Batas atas yang bernilai positif berupa riba, sementara batas bawahnya bernilai negatif berupa zakat. Pendapat ulama terbagi pada dua kelompok yaitu, mendukung dan bahkan menyanjung-nyajung pemikiran Muhammad Syahrûr, tetapi juga tidak sedikit dari ulama-ulama yang mengkritik dan tidak setuju dengan metode dan pemikiran yang di soundingkan oleh Muhammad Syahrûr. 
Demikianlah makalah tentang Muhammad Syahrûr; theory of limit (teori batas) ini penulis buat, tentunya dari penulisan makalah ini jauh dari kesempurnaan dan tak akan luput dari kesalahan. Oleh karena itu, kritik dan saran yang membangun untuk perbaikan makalah ini sangatlah penulis harapkan. Akhirnya billaahi fii sabilil haq, fastabiqul khairaat.

\section{DAFTAR PUSTAKA}

Abdullah, M. A. (2004). Neo Ushul Fiqih menuju ijtihad kontekstual. Fakultas Syari'ah Press dan Forum Studi Hukum Islam.

Armayant, H. (2010). Mengenal Syahrur dan teori batasnya . Kajiantimurtengah. https://kajiantimurtengah.wordpress.com/2010/12/04/mengenal-syahrur-dan-teori-batasnya/

Badarussyamsi, B. (2016). Pembaharuan Islam Muhammad Syahrur. Kajian Pemikiran Islam. https://kajianpemikiranislam.com/pemikiran-pembaharuan-islam-muhammad-syahrur/

Syahrur, M. (1990). Al-Kitâb wa al-Qur'ân: Qirâ'ah Mu'âshirah. Al-Ahali li ath-Thibaah wa anNasyr wa at-Tauzi.

Syahrur, M. (2000). Nahwa Ushûl Jadî-dah li al-Fiqh al-Islâmîy: Fiqh al-Mar'-ah. Al-Ahâlîy li alTaw-zî.

Syahrur, M. (2007). Prinsip dan dasar Hermeneutika Hukum Islam Kontemporer. Sukses Offset. 